\title{
Cryptophyceae population dynamics in an oligo-mesotrophic reservoir (Ninféias pond) in São Paulo, southeast Brazil
}

\author{
Carlos Eduardo de Mattos Bicudo ${ }^{1,2}$, Carla Ferragut ${ }^{1}$ and Marina R. Massagardi ${ }^{1}$
}

Received: 31.01.2008; accepted: 12.02.2009

\begin{abstract}
Cryptophyceae population dynamics in an oligo-mesotrophic reservoir (Ninféias Pond) in São Paulo, southeast Brazil). Vertical and temporal dynamics of Cryptophyceae population was studied in an oligo-mesotrophic reservoir, the Ninféias Pond, located in the Parque Estadual das Fontes do Ipiranga, south of the Municipality of São Paulo, state of São Paulo, southeast Brazil. Material studied was collected from January to December 2000. Individual specimens of Cryptophyceae were present in all samples. Thermal stratification and mixing processes do not seem to directly influence temporal distribution of Cryptophyceae, but may interfere in their vertical distribution. Four out of the 10 species presently identified (C. brasiliensis, C. curvata, $C$. erosa and C. marssonii) presented greatest population densities and highest frequency of occurrence. PCA showed that the species' vertical distribution scale was more important towards ordination of samples. Greatest growth of $C$. erosa was noticed below $1 \mathrm{~m}$ depth in all months sampled. Cryptomonas brasiliensis was highly representative at the surface of reservoir, mainly during the warmer months (January-February, October and November). Considering the temporal scale, results did not demonstrate seasonal distribution of Cryptophyceae, but in the vertical scale, results evidenced a heterogeneous distribution of the group.
\end{abstract}

Key words: Brazil, Cryptophyceae, population dynamics, oligo-mesotrophic urban reservoir

RESUMO - (Dinâmica da população de Cryptophyceae em um reservatório oligo-mesotrófico (Lago das Ninféias) em São Paulo, Brasil sudeste). A dinâmica vertical e temporal das populações de Cryptophyceae foi estudada em um ambiente oligo-mesotrófico - Lago das Ninféias - situado no Parque Estadual das Fontes do Ipiranga, sul do Município de São Paulo, estado de São Paulo, região sudeste do Brasil. O material estudado foi coletado de janeiro a dezembro de 2000. A presença de representantes da classe Cryptophyceae foi detectada em todas as amostras coletadas. Estratificação térmica e mistura parecem não ter influência direta sobre a distribuição temporal das Cryptophyceae, mas podem atuar sobre a repartição vertical de suas espécies. Das 10 espécies identificadas, quatro (C.brasiliensis, C.curvata, C. erosa and C.marssonii) apresentaram as maiores densidades populacionais e as mais altas freqüências de ocorrência. A ACP mostrou que a escala vertical de distribuição das espécies pesou mais na ordenação das unidades amostrais. A maior densidade de C. erosa foi detectada abaixo de $1 \mathrm{~m}$ de profundidade em todos os meses amostrados. Cryptomonas brasiliensis foi altamente representativa na superfície do reservatório, principalmente, durante os meses mais quentes do ano (janeiro, fevereiro, outubro e novembro). Na escala temporal, os resultados não demonstraram distribuição sazonal das Cryptophyceae, porém, na escala vertical, tais resultados mostraram uma distribuição heterogênea das espécies.

Palavras-chave: Brasil, Cryptophyceae, dinâmica de populações, reservatório urbano oligo-mesotrófico

\section{Introduction}

Cryptophyceae are cosmopolitan, but only very seldom the dominant organism in the system. Taxonomy of these algae has been receiving considerable attention globally, with a clear tendency towards using the transmission and scanning electron microcopy findings for the identification of genera within the class (Novarino 2003). Their ecology, however, has universally received much less attention, and almost everything that is presently known about it is from the temperate region of the globe.

Cryptophyceae are considered good herbivore food, since they are easily digested and do not possess toxins (Barone \& Naseli-Flores 2003), a fact that grants the group an important role in the trophic web of aquatic ecosystems, mainly those warm and shallow. Cryptophyceae competitiveness is enhanced by the presence of flagella, which allow their vertical migration between water strata of optimal light and

1. Instituto de Botânica, Caixa Postal 3005, 01061-970 São Paulo, SP, Brazil

2. Corresponding author: cbicudo@terra.com.br 
nutrient concentration conditions (Jansson et al. 1996). Besides having unique morphological characteristics, Cryptophyceae have a considerable evolutive importance (Menezes \& Novarino 2003). Klaveness (1988) emphasized the need for greater knowledge about the Cryptophyceae, and Wetzel (2001) called the attention to how few generalizations there are about the ecology and survival strategies of representatives of this algal class.

Ideas about the phototrophic Cryptophyceae preferences date from before 1950, when knowledge of these plants' ecology was strongly directed by the research with Chilomonas paramecium Ehrenberg, a colorless representative of the class. Besides not being abundant, information on the ecology of Cryptophyceae is also extremely dispersed in the literature. Furthermore it is usually restricted to a few lines in a more broad context, i.e. to that of the periphyton or phytoplankton community ecology (long term studies: Holopainen et al. 2003, Brettum \& Halvorsen 2004; short-term studies: Izaguirre et al. 2004, Nedbalová et al. 2006, Nabout et al. 2006). In just a very few instances, research dealt with only the Cryptomonads (Barone \& Naselli-Flores 2003).

Knowledge of the Cryptophyceae ecology is scarce particularly for the tropical region of the world. Barone \& Naselli-Flores (2003) studied the seasonal dynamics and distribution of Cryptophyceae species in the temperate region. For Brazil, just considering the specific studies on Cryptophyceae, emphasis should be given to those taxonomically oriented by Castro et al . (1991), Castro \& Bicudo (2007) and Menezes \& Souza (2001). Regarding ecology, the paper of Menezes \& Novarino (2003) deserves mention, which reported the existence of high diversity of Cryptophyceae in Brazil, but also mentioned that the population dynamics of the group remains very little understood.

For the Parque Estadual das Fontes do Ipiranga (PEFI), Cryptophyceae species are commonly included among the main descriptive ones of the planktonic (Tucci 2002, Lopes et al. 2005, Biesemeyer 2005, Fonseca 2005) and periphytic (Vercellino 2001, Barcelos 2003) communities. Experimental studies observed the replacement of Cyanophyceae by Cryptophyceae species under mesotrophic conditions (Crossetti \& Bicudo 2005), and the association of Cryptomonas erosa to the high $\mathrm{N}$ availability in the system (Ferragut 2004). Considering the seasonality of PEFI phytoplankton, a strong vertical variation of Cryptophyceae species was detected during the winter (Ramírez 1996) and, more recently, its steady presence throughout an annual cycle was documented (Fonseca 2005).

Considering the importance of Cryptophyceae as environment descriptive species, as well as of the phytoplankton and periphytic communities, particularly in the PEFI reservoirs, the present research focused on the Cryptophyceae community structure in an oligo-mesotrophic reservoir (Ninféias Pond), aiming at identifying patterns for their spatial and/or temporal distribution in the system.

\section{Material and methods}

Locally called Ninféias Pond, the system is in fact a reservoir inserted in the city of São Paulo urban area and, more specifically, in the PEFI, Parque Estadual das Fontes do Ipiranga (2338'08"$23^{\circ} 40^{\prime} 18^{\prime \prime} S$ and $46^{\circ} 36^{\prime} 48^{\prime \prime}-46^{\circ} 38^{\prime} 00^{\prime \prime} \mathrm{W}$ ), southeast of the Municipality of São Paulo. Reservoir was built by damming the Pirarungaua creek in an attempt to give the São Paulo Botanical Gardens a more beautiful landscaping. Reservoir is a shallow system with oligomesotrophic characteristics (D. Bicudo et al. 2002). According to C. Bicudo et al. (2002), reservoir's maximum depth is $3.6 \mathrm{~m}$, maximum length $187 \mathrm{~m}$, maximum width $52.6 \mathrm{~m}$, volume $7,170 \mathrm{~m}^{3}$, and mean residence time 7.2 days.

Material was collected during the period JanuaryDecember 2000. Sample units used for qualitative and quantitative analyses are part of the documentcollection of the Aquatic Ecology Laboratory of the Ecology Department of the Instituto de Botânica.

For determination of physical, chemical and biological variables, water samples were collected in replicate $(\mathrm{n}=2)$ at four depths (subsurface, $1 \mathrm{~m}$, $2 \mathrm{~m}$ and $\pm 20 \mathrm{~cm}$ from the bottom) using a van Dorn sampler. The following physical and chemical water variables were analyzed: temperature (Yellow Spring Instr.), transparency (Secchi disc), electric conductivity (Yellow Springs Instr.), alkalinity (Golterman \& Clymo 1971), dissolved oxygen (Golterman et al. 1978), $\mathrm{pH}$ (Yellow Spring Instr.), free $\mathrm{CO}_{2}$ and nitrate (Mackereth et al. 1978), ammonium (Solorzano 1969), orthophosphate (Strickland \& Parsons 1960), total phosphorus (TP) and total nitrogen (TN) (Valderrama 1981). Nitrogen-ammonium concentrations were added to obtain final TN levels. Samples for the nutrients dissolved fraction were filtered using GF/F filters under low pressure $(<0.5 \mathrm{~atm})$. Water relative thermal resistance (RTR) was calculated for every 50 cm depth (Dadon 1995). 
Air temperature, wind speed, solar radiation and rain precipitation data were provided by the "Alexander Postoiev" Meteorological Station of the CIENTEC, Center for Science and Technology of the Universidade de São Paulo located within the PEFI area.

Chlorophyll- $a$ analyses corrected for phaeophytin were carried out at most within a week from the sampling day using $90 \%$ ethanol extraction (Sartory \& Grobbelaar 1984). Taxonomic samples were preserved with $4 \%$ formaldehyde water solution and identification to species level was carried out mainly according to Castro et al. (1991) and Castro \& Bicudo (2007). Phytoplankton counting was carried out according to Utermöhl (1958), and subsample sedimentation time in chamber followed Lund et al. (1958). The material used for counting was preserved with water lugol $1 \%$ solution and quantification was performed using a Zeiss (Invertoskop) inverted microscope. Biovolume of each species was obtained by comparison with the geometric solid taken either isolate or combined, that would most approach the cell form (Hillebrand et al. 1999).

Based on their frequency of occurrence $(\mathrm{F})$, species were considered rare $(\mathrm{F}<20 \%)$, common $(\mathrm{F}$ $=20-50 \%)$ and constant $(\mathrm{F}>50 \%)$.

Univariate analyses were carried out, the arithmetic mean used as central tendency measure. For a combined evaluation, Multivariate Principal Components Analysis (PCA) was applied to the abiotic and biological data. During both analyses, covariance matrices were used with data transformed by $\log$ (x +1 ). Data transformation for PCA was accomplished by using the FITOPAC program (Shepherd 1996), and for the analyses themselves PC-ORD, version 4.10 (McCune \& Mefford 1999).

\section{Results}

Rain precipitation was greater in January, February and December (rainy period), and less in June-August (dry period) (figure 1). Air temperature was greater from January to March and from October to December, reaching $23{ }^{\circ} \mathrm{C}$. However, it did not exceed $15{ }^{\circ} \mathrm{C}$ in July (figure 1). During the study period, solar radiation varied from 12 to $19 \mathrm{MJ} . \mathrm{m}^{-2}$ in May and December, respectively. Solar radiation reached the highest levels in January and December, and the lowest in June-July. Wind speed was greatest in February $\left(2 \mathrm{~m} \mathrm{~s}^{-1}\right)$ and lowest in June $\left(1 \mathrm{~m} \mathrm{~s}^{-1}\right)$.

Vertical distribution of turbidity values was heterogeneous during the rainy period, mainly in January (figure 2) when values were the highest of the year. Electric conductivity was greater during the latter period and presented a heterogeneous vertical distribution during the rainy season, the greatest values detected at the bottom of reservoir (figure 2). $\mathrm{pH}$ values were heterogeneous during the entire study period (figure 2).

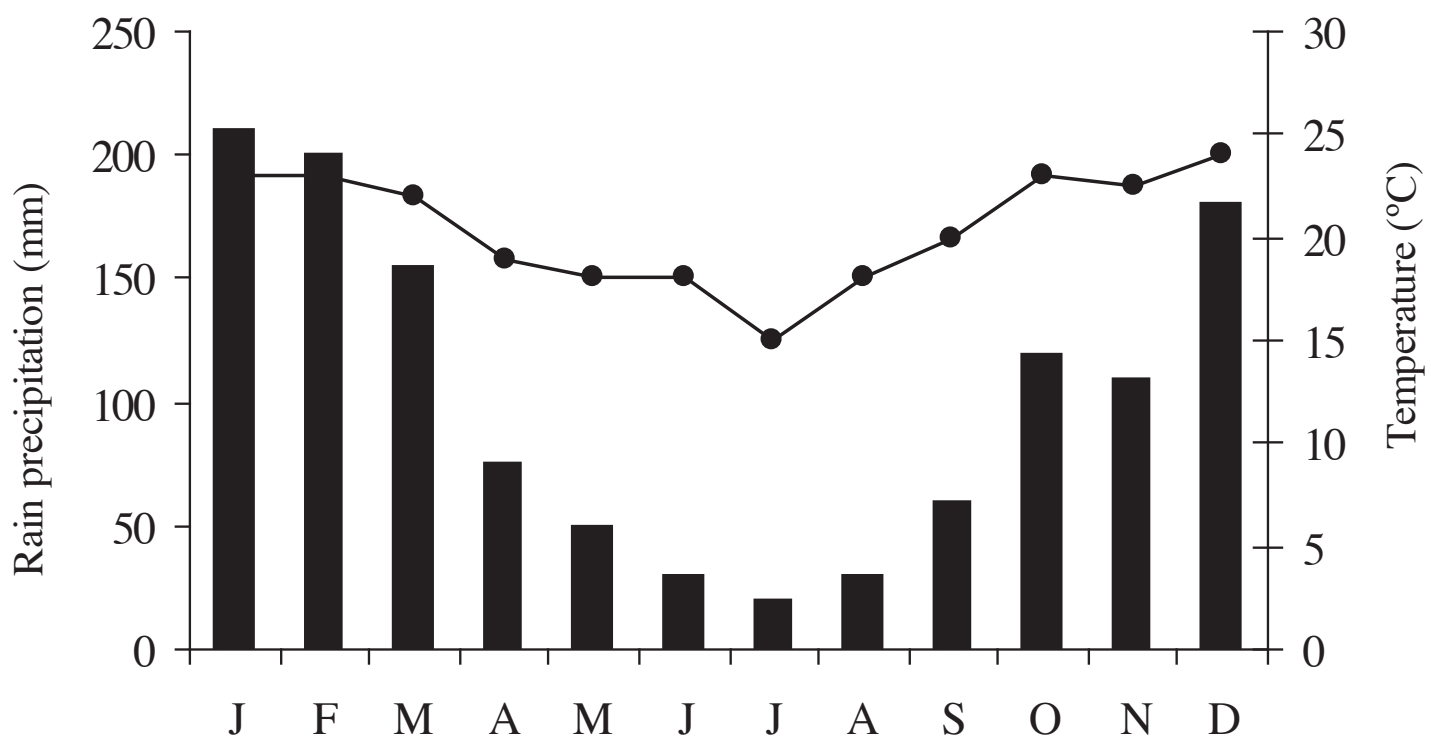

Figure 1. Monthly variation of rain precipitation ( $\mathbf{\square}$ ) and air temperature (•) during the period January-December 2000. 

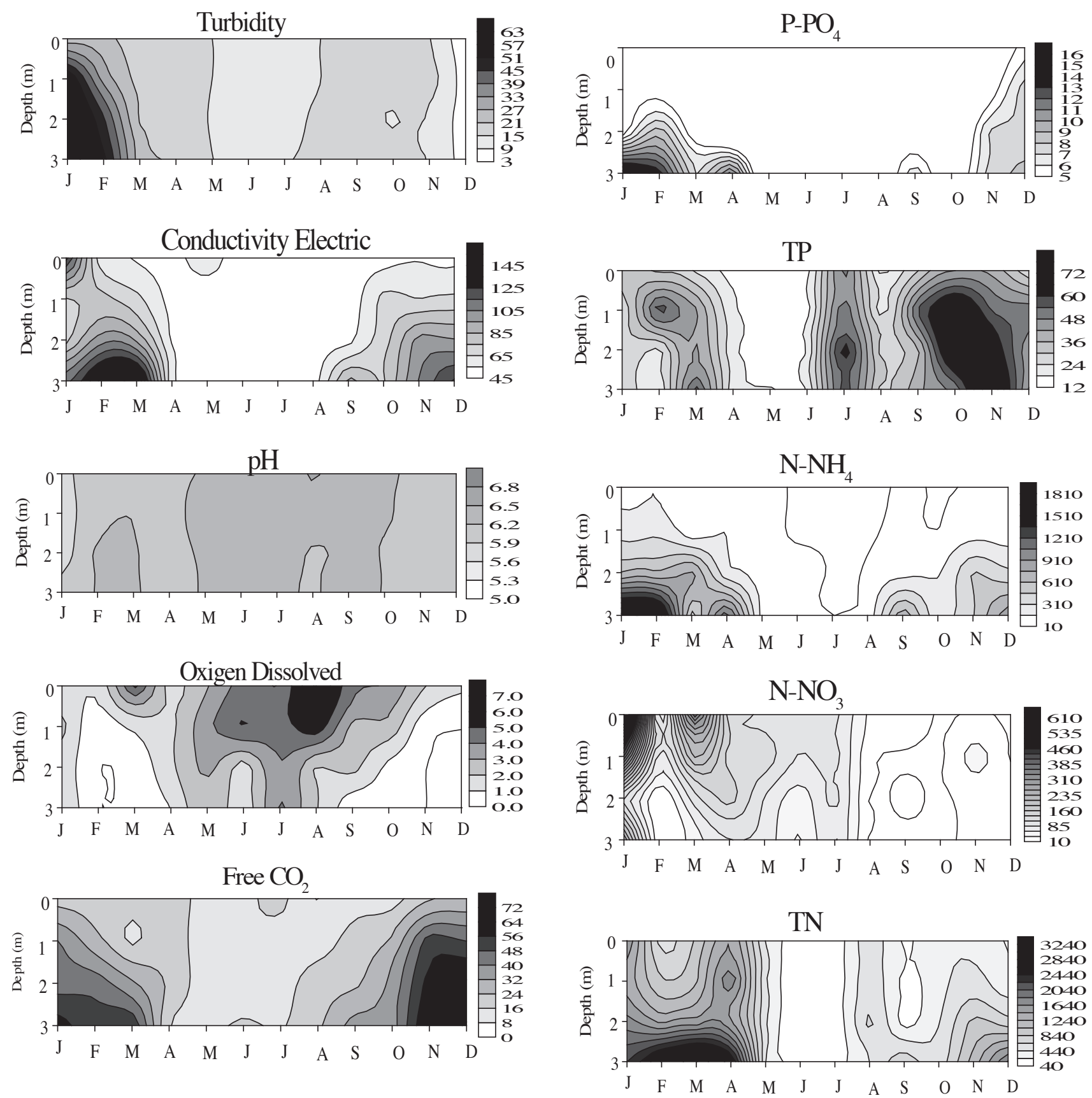

Figure 2. Depth and time diagram of turbidity (NTU), electric conductivity $\left(\mu \mathrm{S} \mathrm{cm}^{-1}\right), \mathrm{pH}$, dissolved oxygen $\left(\mathrm{mg} \mathrm{L}^{-1}\right)$ and free $\mathrm{CO}_{2}\left(\mathrm{mg} \mathrm{L}^{-1}\right)$ values isolines at the Ninféias Pond during the period January-December 2000.

Dissolved oxygen (DO) values were greater at the surface of reservoir during the entire study period, reaching anoxia at the bottom of the system. In the temporal scale, gases concentration in the water was greater during the dry than in the rainy period (figure 2). Free $\mathrm{CO}_{2}$ concentration was greater at the bottom of reservoir, mainly from January to March and from October to November (figure 2).

Figure 3. Depth and time diagram of total and dissolved nutrient isolines $\left(\mu \mathrm{g} \mathrm{L}^{-1}\right)$ at the Ninféias Pond during the period JanuaryDecember 2000.

Total phosphorus (TP) and orthophosphate greatest concentration was measured at the bottom of the system, particularly during the rainy period in October, November and December (figure 3). Ammonium concentration was always high at the bottom of reservoir during the rainy period and very homogeneous in June and July, however, its overall concentration in the system was low (figure 3 ). Nitrate 
greatest concentration was measured at the surface of the reservoir from January to April, being not detected at the bottom (figure 3 ). The greatest concentration of nitrate occurred in January and February at $2 \mathrm{~m}$ depth (figure 3). Total nitrogen (TN) greatest concentration was detected at the bottom of the reservoir during the rainy period, but its overall distribution in the system was heterogeneous (figure 3 ).

Integrated analysis of limnological variables (PCA) resumed $76.8 \%$ of the data total explicability in its two first axes (figure 4). At the positive side of axis 1 , the dry period samples were located associated to the highest dissolved oxygen and $\mathrm{pH}$ values, both highly correlated with axis 1 (respectively, $r=0.759$ and $r=0.411$ ). At the negative side of the same axis, most of the rainy period samples were located associated to the highest values of ammonium ( $r=-0.981)$, total nitrogen $(r=-0.836)$, electric conductivity $(r=-0.795)$, free $\mathrm{CO}_{2}(r=$ $-0.725)$, chlorophyll- $a(r=-0.692)$, orthophosphate $(r=-0.662)$, nitrite $(r=-0.585)$ and turbidity $(r=$ $-0.470)$. The first axis $(51.5 \%)$ clearly separated the rainy period from the dry period. Consequently, axis 1 of the PCA represented the temporal variation. The second axis $(25.3 \%)$ presented nitrate $(\mathrm{r}=-0.699)$ and temperature $(r=0.623)$ with great positive correlation, but $\mathrm{pH}(r=-0.525)$ and PDT $(r=-0.588)$ with negative correlation with axis 1 .

Thermal stratification was detected from January to March and from August to December (figure 5). In the remaining months (April to July), thermal profile was homogeneous, the low $(<10)$ relative thermal resistence values and temperature difference between surface and bottom of reservoir charaterizing a mixing period.

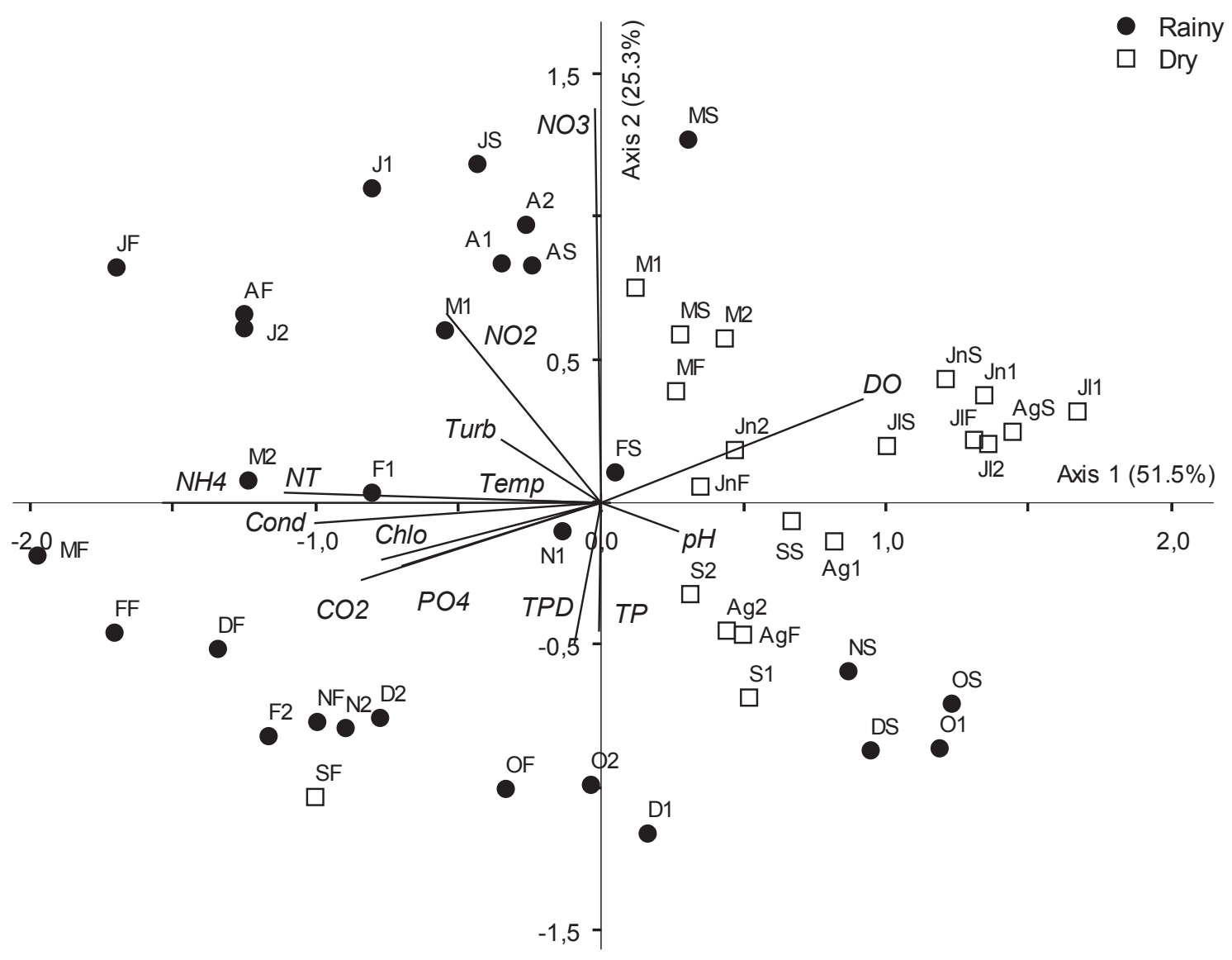

Figure 4. Biplot of PCA for the mean values of abiotic variables of depths and months at the Ninféias Pond during the period JanuaryDecember 2000. Abbreviations: $\mathrm{NH} 4=$ Ammonium, Cond $=$ Conductivity, $\mathrm{DO}=$ Dissolved Oxygen, $\mathrm{Temp}=\mathrm{Temperature}, \mathrm{NO}_{3}=\mathrm{Nitrate}$, $\mathrm{PO}_{4}=$ Orthophosphate, $\mathrm{pH}=\mathrm{pH}, \mathrm{TDP}=$ Total Dissolved Phosphorus, $\mathrm{TN}=$ Total Nitrogen, $\mathrm{TP}=$ Total Phosphorus, $\mathrm{CO}_{2}=\mathrm{Free}^{\mathrm{CO}} \mathrm{C}_{2}$, Turb = Turbidity. Sampling units abbreviations: first letters refer to months and the last ones to depths $(\mathrm{S}=$ surface, $1=1 \mathrm{~m}, 2=2 \mathrm{~m}$ and $\mathrm{B}=$ bottom). 

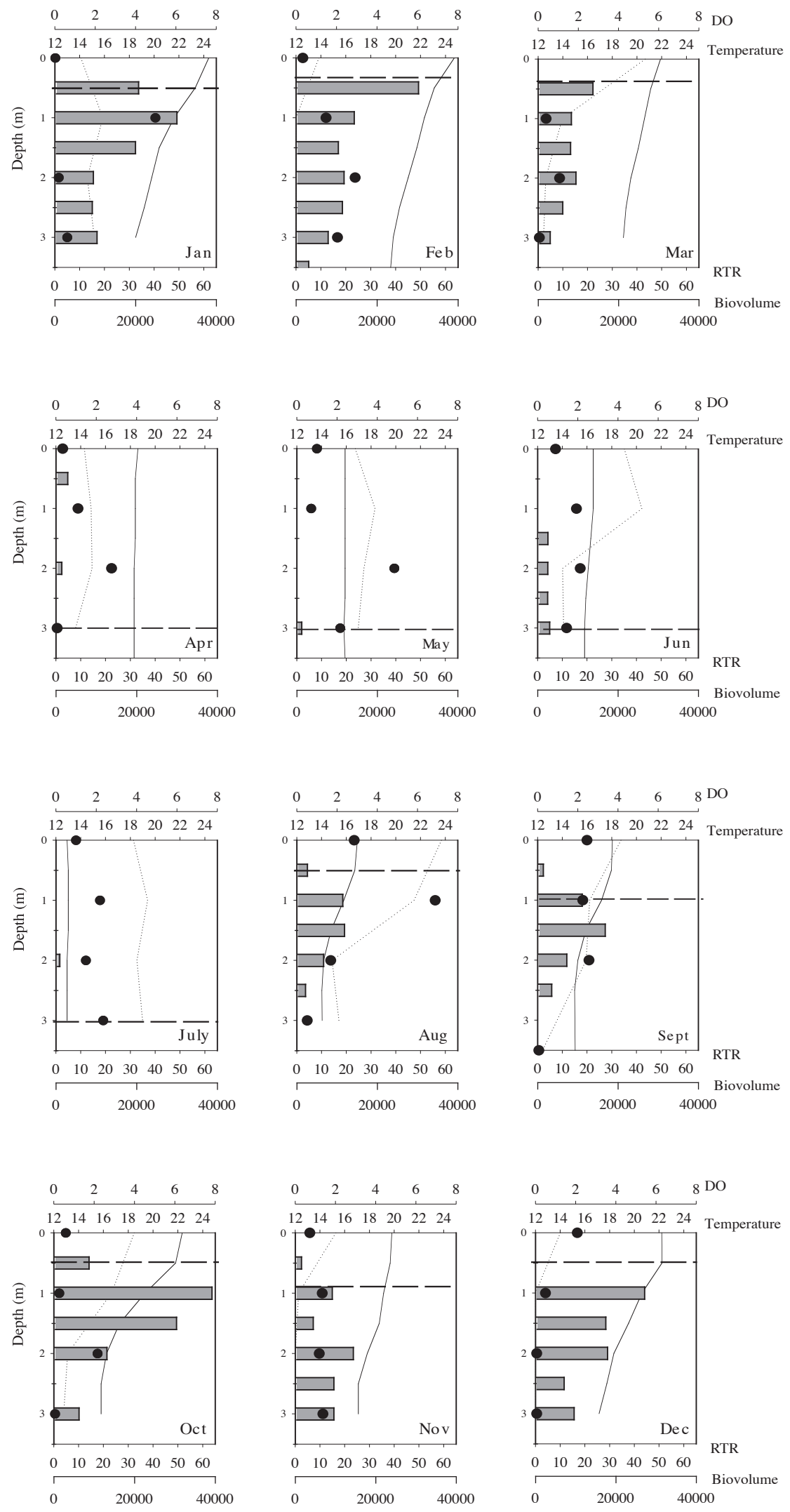

Figure 5. Vertical profile of water temperature $\left({ }^{\circ} \mathrm{C},-\right)$, dissolved oxygen $\left(\mathrm{mg} \mathrm{L}^{-1},----\right)$, mixing zone $(--, \mathrm{m})$, relative thermal resistance $(\mathrm{RTR},-)$ and total biovolume of Cryptophyceae $\left(\mu \mathrm{m}^{3} \mathrm{~mL} \bullet\right)$ at the Ninféias Pond during the period January-December 2000 


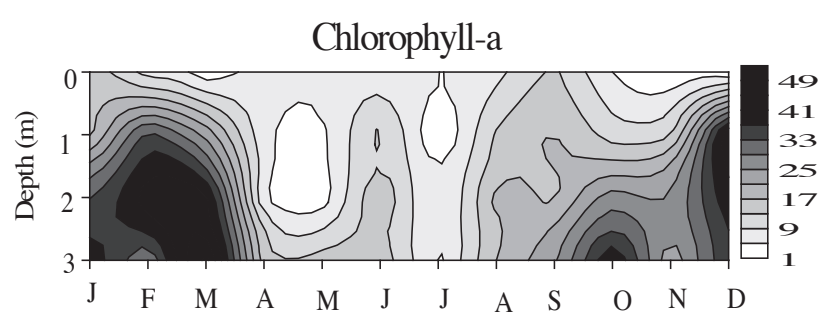

Figure 6. Depth and time diagram of chlorophyll- $a\left(\mu \mathrm{g} \mathrm{L}^{-1}\right)$ of phytoplankton isolines at the Ninféias Pond during the period January-December 2000.

Phytoplankton chlorophyll- $a$ at the Ninféias Pond presented a heterogeneous distribution from January to April and again from September to December (figure 6). Greatest values were detected at 1 to $3 \mathrm{~m}$ depth, mostly during the rainy period (March to December).

Members of the Cryptophyceae were present at all depths during the entire study period. The following 10 species, all of Cryptomonas, were identified: $C$. brasiliensis Castro et al., C. curvata Ehrenberg, $C$. erosa Ehrenberg var. erosa, C. marssonii Skuja, C. obovata Skuja, C. ovata Ehrenberg var. ovata, C. phaseolus Skuja, C. platyuris Skuja, C. tenuis Pascher and $C$. tetrapyrenoidosa Skuja. The most common species was C. erosa, whose frequency of occurrence varied between $83 \%$ - 100\%.

Regarding the temporal scale, members of Cryptophyceae were observed all year round, however, its total density and total biovolume presented a heterogeneous vertical distribution, the greatest values measured in between 2 and $3 \mathrm{~m}$ depth (figure 7). From the 10 species identified, four presented the highest frequency of occurrence as well as the greatest population density $(C$. brasiliensis, $C$. curvata, C. erosa and C. marssonii).

Considering the Cryptophyceae species temporal and spatial distribution, $C$. brasiliensis was the best represented one at the surface of reservoir, mainly during the warmer months of the study period (January-February and October-November); however, its representation decreased significantly from $1 \mathrm{~m}$ depth down (figures 8-9).

From the species studied, C. brasiliensis was the only one to have a stratified vertical distribution, with a decreasing population density towards the bottom of reservoir all year round. Cryptomonas brasiliense presented $100 \%$ frequency of occurrence at the subsurface, but at the bottom it was considered rare $(<17 \%)$.
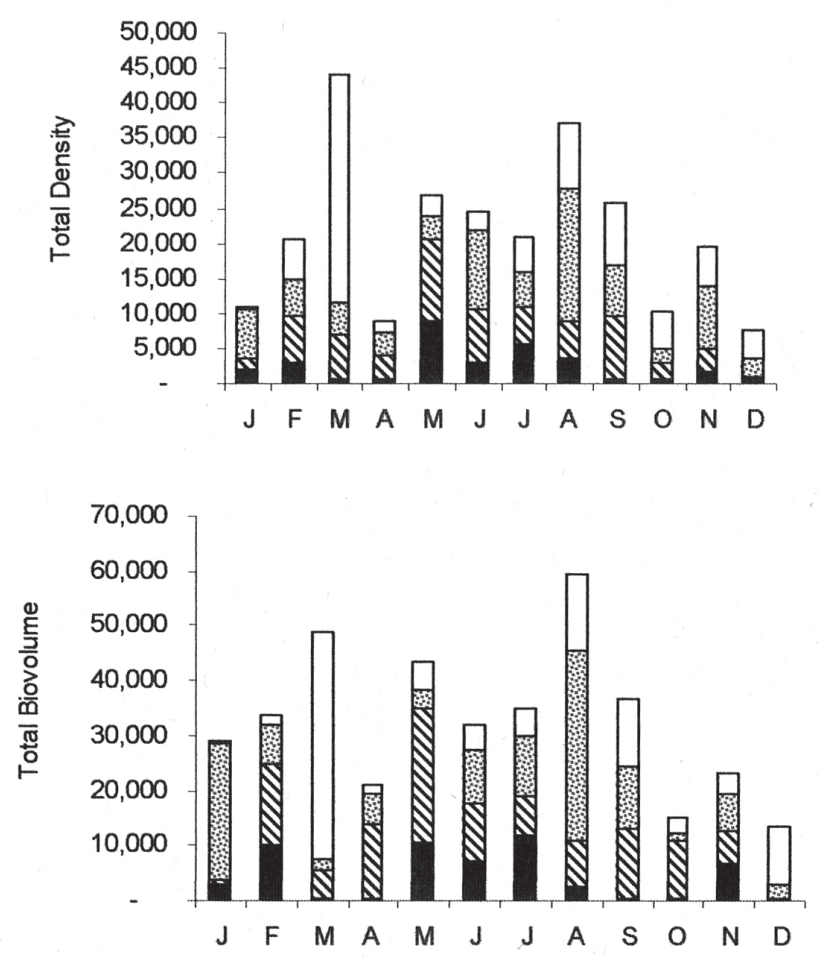

Figure 7. Temporal variation of total density (ind. $\mathrm{L}^{-1}$ ) and total biovolume $\left(\mu \mathrm{m}^{3} \mathrm{ml}^{-1}\right)$ of Cryptophyceae at the Ninféias Pond during the period January-December $2000(\square$ = surface, $1 \mathrm{~m}, \boldsymbol{\nabla}=2 \mathrm{~m}$ and $\square=$ bottom).

The other species with great density was C.erosa, mainly at $1 \mathrm{~m}$ and $2 \mathrm{~m}$ depth during the dry period. Still about $C$. erosa, the species considerably increased its relative density in the reservoir reaching $100 \%$ at the depth of $2 \mathrm{~m}$ in December and at the bottom in MarchApril, September-October and December (figures 8-9).

Cryptomonas marssonii showed the most uniform distribution at the depth of $1 \mathrm{~m}$ in October (figures $8-9$ ), when compared to those of the other species. Latter species was well represented at all depths and its frequency of occurrence varied between $42 \%$ and $92 \%$, but its vertical distribution was more heterogeneous during the stratification (rainy) period, tending to homogeneity during the dry period (figure 9).

All other species were poorly represented in the reservoir during the entire study period. Cryptomonas curvata presented greater population density in the upper strata, and lower density and frequency of occurrence at the bottom of reservoir (figures 8-9).

Integrated analysis of the biological features - PCA integrated analysis of the biological data resumed $46.3 \%$ of the total variability of data in its first two axes (figure 10). At the negative side of 
Surface
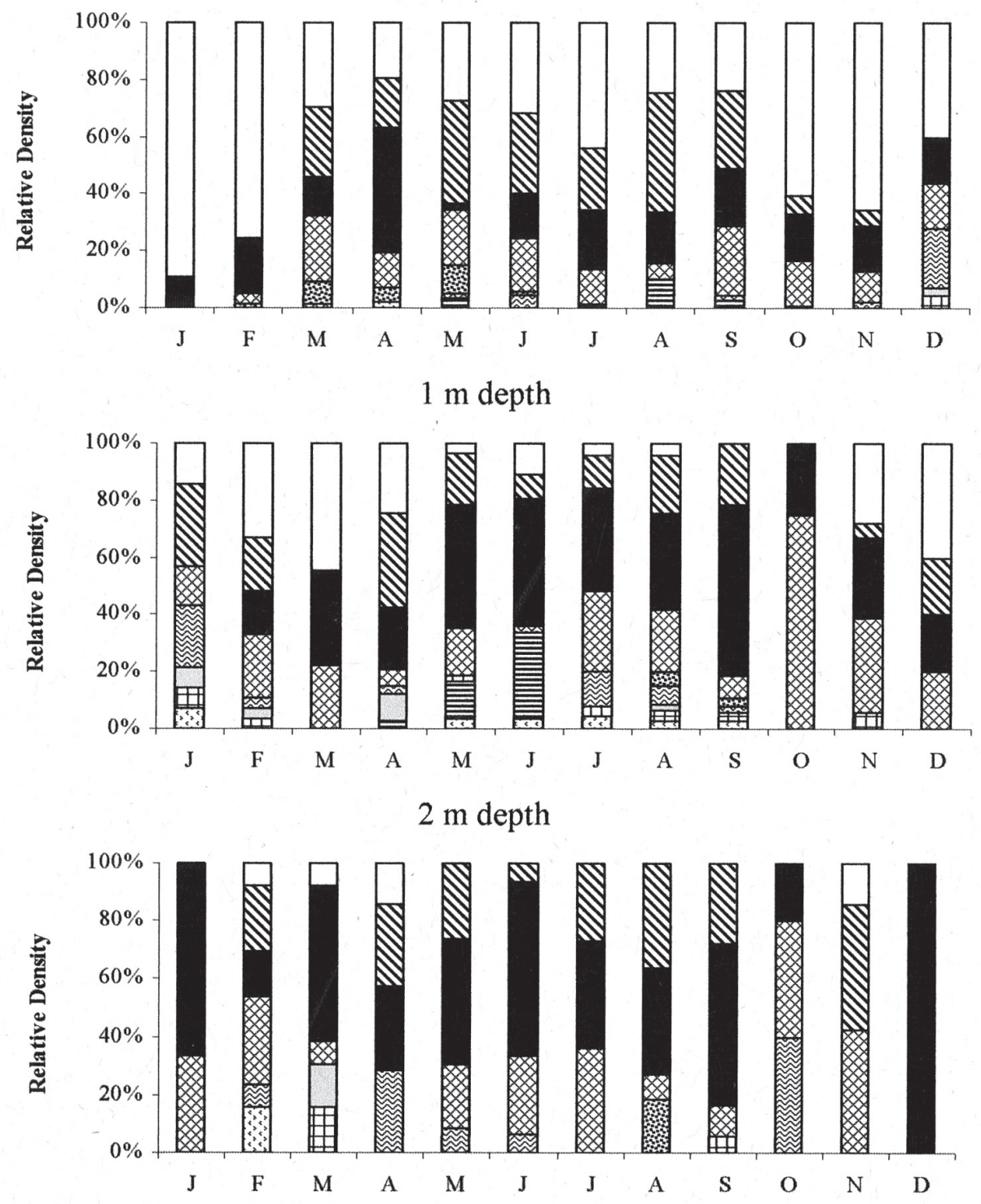

Bottom

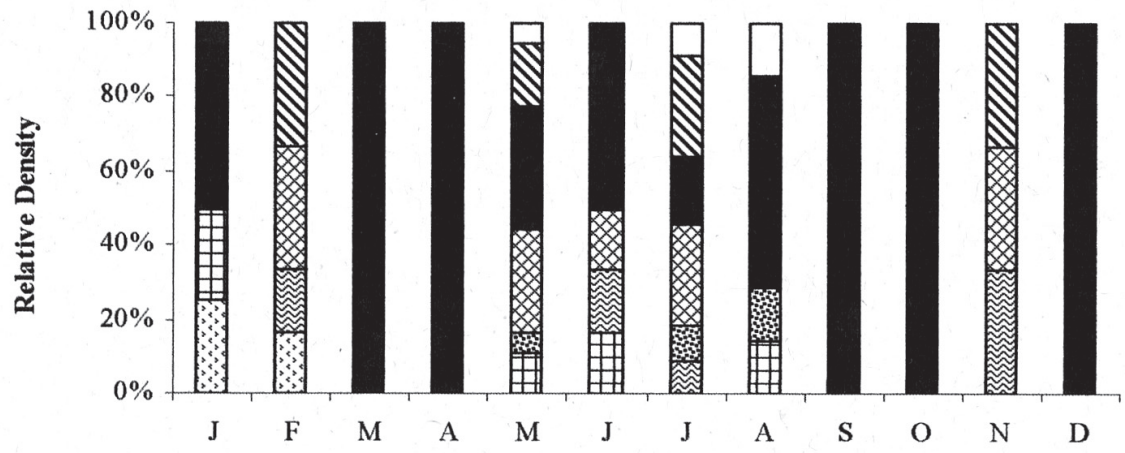

Figure 8. Temporal and spatial variation of relative density of Cryptophyceae species based on population density at the Ninféias Pond

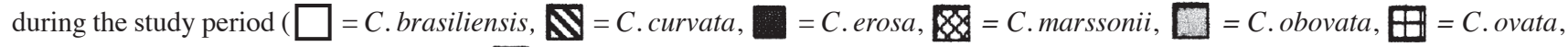

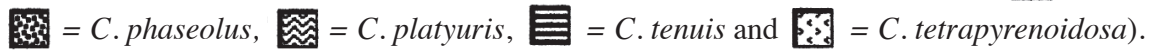



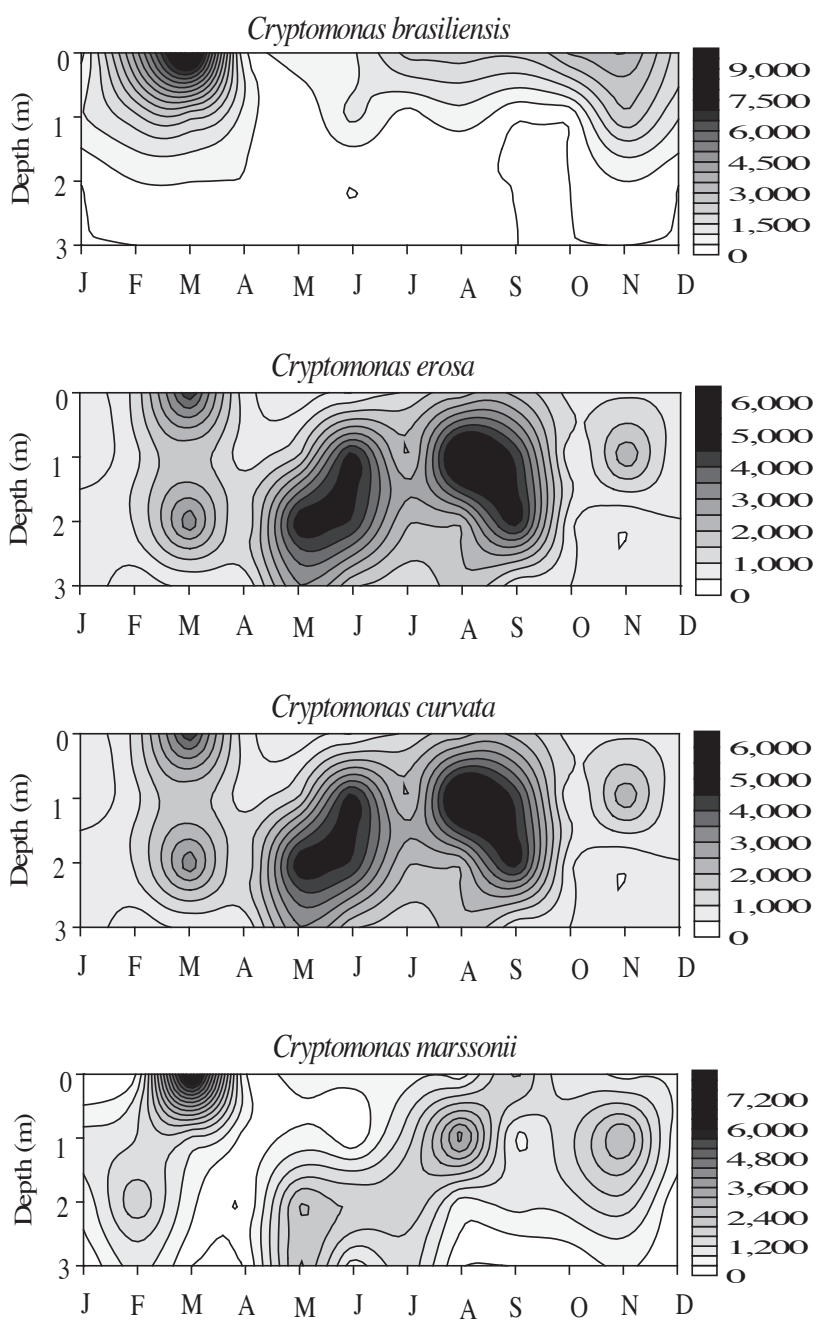

Figure 9. Depth and time diagram of population density (ind $\mathrm{L}^{-1}$ ) isolines of most representative Cryptophyceae species at the Ninféias Pond during the period January-December 2000.

axis 1 were located most sampling units from the subsurface and $1 \mathrm{~m}$ depth associated with the greatest densities of $C$. curvata $(r=-0.851), C$. marssonii $(r=$ -0.724), C. brasiliensis $(r=-0.647)$ and $C$. platyuris $(r=-0.572)$, which presented high correlation with axis 1 . Differently, at the positive side were located most of the sampling units from the bottom of reservoir associated with the low densities of the Cryptophyceae. So, axis 1 represented the vertical scale distribution of Cryptophyceae species. Despite of its low explicability, axis 2 showed $C$. brasiliensis high negative correlation $(r=-0.678)$ with that axis, associated with all subsurface sampling units.

\section{Discussion}

Cryptophyceae have the peculiarity of their continuous presence in the aquatic systems, i.e. they occur during the entire year. Their highest and lowest population peaks usually follow disturbances like, for instance, mixings due to wind action or precipitation periods, not always being connected with seasonality (Reynolds \& Reynolds 1985). Cryptophyceae usually increase their density in the system as other algal groups decreased theirs, i.e. as a temporary niche opens for their occupation. This kind of behavior led to qualification of Cryptophyceae as "opportunistic", i.e. fast growing algae with a short life cycle, efficient dispersal mechanisms, and the allocation of a great amount of energy for their reproduction; in other words, Cryptophyceae are considered to be r-strategists (Sommer 1981, Klaveness 1988).

According to descriptive and multivariate analyses of abiotic data, two distinct study periods were identified, a dry and a rainy one. The rainy period is characterized by the presence of thermal and chemical stratification and of greater nutrient and free $\mathrm{CO}_{2}$ availability, as opposed to the dry one that is typical by water circulation and high DO concentration.

Cryptophyceae species were present during all months and reservoir strata in the present study, however, the greatest population growth occurred in the intermediate strata ( $1 \mathrm{~m}$ and $2 \mathrm{~m}$ deep). At the Ninféias Pond, Biesemeyer (2005) found high Cryptophyceae density in the phytoplankton of intermediate and lower strata, mainly during the rainy period of a nictemeral study. According to Fonseca (2005), Ninféias Pond presents a phytoplankton flora constituted by many myxotrophic species. Cryptophyceae populations were reported dominant in the deep strata (Lovell \& Konopka 1985, Gervais 1998). Various mechanisms are pointed out to explain the greater development of Cryptophyceae populations at the deepest strata of reservoir, among which their tolerance to low light intensity, which is associated to their capacity of assimilating nutrient by fagotrophy (Reynolds 1984, Barone \& Naseli-Flores 2003, Jones 2000, Lepistö $\&$ Holopaien 2003). According to Barone \& NaseliFlores (2003), photoadaptive strategy and formation of resting forms are physiological mechanisms that could explain the Cryptophyceae success in shallow systems like the Ninféias Pond.

Based on Reynolds et al. (2002) functional groups, genus Cryptomonas belongs to group Y, whose species are well adapted to living in several kinds of habitats, but mainly shallow enriched ones.

In moderately productive steady stratified lakes, development of a phytoplankton community below 


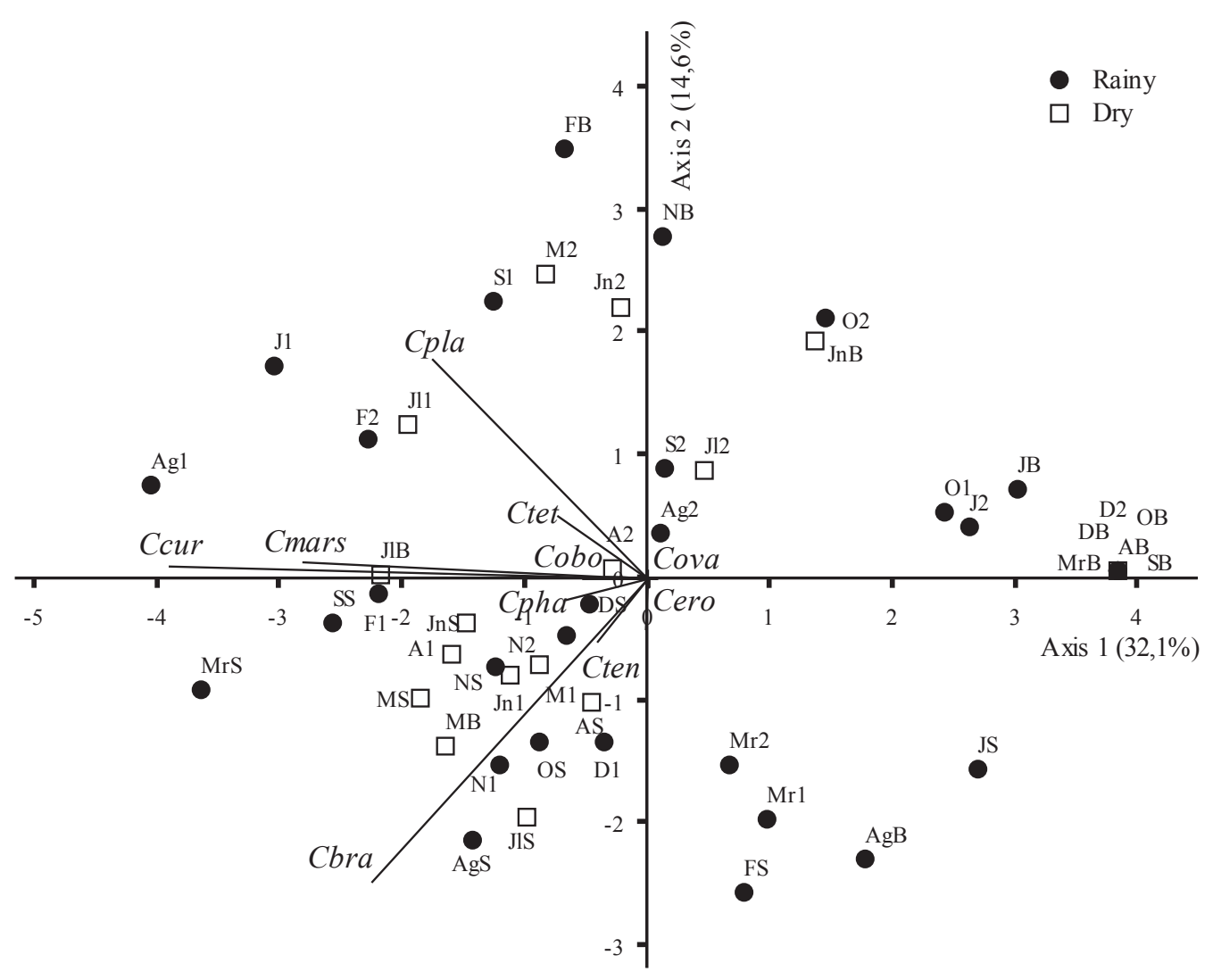

Figure 10. Biplot of PCA for the density of species Cryptophyceae in the depths and months at the Ninféias Pond during the period January-December 2000. Sampling units abbreviations: first letters refer to month and the last ones to depth $(\mathrm{S}=\mathrm{surface}, 1=1 \mathrm{~m}, 2=2$ $\mathrm{m}$ and $\mathrm{B}=$ bottom). Cbra $=$ Cryptomonas brasiliensis, Cero $=$ Cryptomonas erosa, Cmars $=$ Cryptomonas marssonii, Cpha $=$ Cryptomonas phaseolus, Ctet $=$ Cryptomonas tetrapirenoidosa, Ccur $=$ Cryptomonas curvata, Cten $=$ Cryptomonas tenuis, Cpla $=$ Cryptomonas platyuris, Cobo $=$ Cryptomonas obovata and Cova $=$ Cryptomonas ovata .

the thermocline may occur, which leads to a deep chlorophyll- $a$ maximum (Reynolds 1997). In a dimitic, meso-eutrophic lake, Gervais (1998) observed that the greatest Cryptophyceae population growth occurred below the oxycline and near the chemocline, their variability being directed by light availability and grazing. In the present study, the greatest population development was observed in the intermediate strata, the maximum biomass and density peaks documented close to the thermocline during the stratification months (January-March and August-December) and during the mixing ones close to oxycline. Ninféias Pond presented the highest photosynthetic biomass in the intermediate strata (Biesemeyer 2005) and at the bottom (Fonseca 2005), a fact that was presently also observed.

Considering the individual species vertical distribution of the present study, only C. brasiliensis showed a heterogeneous vertical profile, mainly during the stratification period (January-March and OctoberNovember) remaining, however, more restricted to the subsurface during the mixing period. Biesemeyer (2005) observed, at the Ninféias Pond, association of C. brasiliensis with the rainy period, a time in which all species were present in the entire water column.

Cryptophyceae population seasonal distribution was not presently observed. In the temperate region, Barone \& Naseli-Flores (2003) noticed that in Sicilian lakes sensitivity of such algae to filter-feeding organisms would explain their seasonal dynamics, since the maximum biomass peak was detected during late winter and early spring when light and temperature availability was low and grazing pressure well reduced. In a nictemeral study of phytoplankton, Ramírez (1996) observed significant vertical variation of Cryptophyceae, except during the spring, being more striking during the winter. In Brazil, Nabout et al. (2006) reported dominance of Cryptophycae, chiefly 
of $C$. erosa, during the dry period, at the surface of floodplain lakes of the Araguaia River.

At the Ninféias Pond, C.erosa is usually referred among the community main descriptive species. In the present study, C. erosa contributed significantly and presented very efficient vertical distribution, being found in all reservoir strata. However, its greatest population density occurred during the dry period and, mainly, in the intermediate strata of reservoir. It should be mentioned that $C$. erosa was the only species found at the bottom of reservoir in some months of the thermal and chemical stratified period (MarchApril, September-October, and December). Kruk et al. (2002) considered C. erosa a well-adapted species to light deficiency conditions.

For the PEFI area, Lopes et al. (2005) reported the occurrence of C. erosa mostly at 3-3.5 m deep and at the bottom of reservoir, because of its lesser demand for light. They also justified the species association with the high levels of TP as an opportunistic feature of all Cryptophyceae. Biesemeyer (2005) noticed that $C$. erosa was influenced by the thermal stratification at the Ninféias' Pond subsurface. Studying the periphyton community, Vercellino (2001) verified relationship between $C$. erosa density peak and the rainy period at the Garças Pond.

Regarding their nutritional requirements, Cryptophyceae are considered euritrophic, i.e. they are able to tolerate a wide spectrum of trophic conditions (Reynolds 1976). Cryptophyceae have a wide environment spectrum, as they are typical of nutrients and organic matter rich waters (Rosen 1981), but they can also tolerate occasional nutrient, especially N depletion (Haffner \& McNeely 1989). In the periphyton community in oligotrophic conditions, $C$. phaseolus was associated with the greatest ammonium content (Vercellino 2001), whereas in the phytoplankton community $C$. erosa was associated with high levels of TP and $\mathrm{P}-\mathrm{PO}_{4}$ during the rainy period, mainly at 3-3.5 m deep and the bottom of reservoir (Lopes et al. 2005). In mesotrophic conditions, presence of C. marssonii was associated with the high $\mathrm{N}^{-\mathrm{NO}_{3}}$ concentrations (Fonseca 2005). Under experimental conditions, Crossetti \& Bicudo (2005) observed association of $C$. curvata, C. erosa and $C$. tetrapyrenoidosa with eutrophic conditions, mostly with TN and TP concentrations. Ferragut (2004) associated the presence of $C$. erosa in the periphyton with the great $\mathrm{N}$ availability in the IAG Pond.

In the present study, great development of Cryptophyceae populations was registered in the intermediate layers of reservoir, where the nutrient availability varied seasonally. Despite the lesser light availability in the intermediate strata of system, which was mainly due to the great abundance of aquatic macrophytes, environmental conditions favored development of Cryptophyceae. Some studies reported that seasonal dynamics seems to be independent of the trophic status of the ecosystem (Barone \& NaselliFlores 2003, Ojala 1993).

Based on the Cryptophyceae biomass in boreal lakes, that the small biovolume species (24 to 593 $\mu \mathrm{m}^{3}$ ) were associated to the high $\mathrm{N}-\mathrm{NO}_{3}$ availability, whereas the great biovolume species $(2,418$ to 4,136 $\mu \mathrm{m}^{3}$ ) to the great TP and $\mathrm{P}-\mathrm{PO}_{4}$ availability (Lepistö $\&$ Holopainen 2003). Relation between vertical migration and nutrient availability was reported by Knapp et al. (2003), the authors concluding that diurnal migration of Cryptomonas spp. in the Cross Reservoir was largely regulated by daily light conditions (photon irradiance and gradient), whereas their abundance is greatly influenced by TP and $\mathrm{NH}_{4}$ levels at the hypolimnion. Cryptophyceae diurnal migration allows these organisms to take advantage of both high nutrients availability during the night and high light intensity during the day (Knapp et al. 2003).

As a rule, Cryptophyceae had their greatest development at the intermediate layers (1 $\mathrm{m}$ and $2 \mathrm{~m}$ ) of Ninféias Pond. According to the temporal scale, however, only $C$. erosa clearly presented greatest development during the dry period. Cryptomonas brasiliensis was the species mostly associated with the superficial stratum, and the only one with heterogeneous vertical distribution during the stratification period and homogeneous during the mixing period. Spatial scale will consequently have greater importance than the temporal one on the dynamics and distribution of Cryptophyceae at the Ninféias Pond.

\section{Acknowledgments}

Authors are indebted to the PIBIC, Programa Institucional de Bolsas de Iniciação Científica of CNPq, Conselho Nacional de Desenvolvimento Científico e Tecnológico Program for fellowship given to Marina R. Massagardi.

\section{Literature cited}

Barcelos, E.M. 2003. Avaliação do perifíton como sensor da oligotrofização experimental em reservatório eutrófico (Lago das Graças, São Paulo). Master of Science Thesis, Universidade Estadual Paulista, Rio Claro. 
Barone, R. \& Naselli-Flores, L. 2003. Distribution and seasonal dynamics of Cryptomonads in Sicilian water bodies. In: L. Naselli-Flores, J. Padisák \& M.T. Dokulil (eds.). Phytoplankton and equilibrium concept: the ecology of steady-state assemblages. Developments in Hydrobiology 172. Kluwer Academic Publishers, Dordrecht, pp. 325-329.

Bicudo, C.E.M., Carmo, C.F., Bicudo, D.C., Henry, R., Pião, A.C.S., Santos, C.M. \& Lopes, M.R.M. 2002. Morfologia e morfometria de três reservatórios do PEFI. In: D.C.Bicudo, M.C. Forti \& C.E.M. Bicudo (orgs.). Parque Estadual das Fontes do Ipiranga (PEFI): unidade de conservação que resiste à urbanização de São Paulo. Secretaria do Meio Ambiente do Estado de São Paulo, São Paulo, pp.143-160.

Bicudo, D.C., Forti, M.C., Carmo, C.F., Bourotte, C., Bicudo, C.E.M., Melfi, A.J. \& Lucas, Y. 2002. A atmosfera, as águas superficiais e os reservatórios no PEFI: caracterização química. In: D.C. Bicudo, M.C. Forti \& C.E.M. Bicudo (orgs.). Parque Estadual das Fontes do Ipiranga (PEFI): unidade de conservação que resiste à urbanização de São Paulo. Secretaria do Meio Ambiente do Estado de São Paulo, São Paulo, pp.161-212.

Biesemeyer, K.F. 2005. Variação nictemeral da estrutura e dinâmica da comunidade fitoplanctônica em função da temperatura da água nas épocas de seca e chuva em reservatório urbano raso mesotrófico (Lago das Ninféias), Parque Estadual das Fontes do Ipiranga, São Paulo. Master of Science Thesis, Instituto de Botânica, São Paulo.

Brettum, P. \& Halvorsen, G. 2004. The phytoplankton of Lake Atnsjøen, Norway: a long term investigation. Hydrobiologia 521: 141-147.

Castro, A.A.J., Bicudo, C.E.M \& Bicudo, D.C. 1991. Criptógamos do Parque Estadual das Fontes do Ipiranga, São Paulo, SP. Algas, 2: Cryptophyceae. Hoehnea 18: 87-106.

Castro, A.A.J. \& Bicudo, C.E.M. 2007. Cryptophyceae. In: C.E.M. Bicudo (org.). Flora Ficológica do Estado de São Paulo. RiMa Editora, São Carlos.

Crossetti, L.O. \& Bicudo, C.E.M. 2005. Structural and functional phytoplankton responses to nutrient impoverishment in mesocosms placed in a shallow eutrophic reservoir (Garças Pond), São Paulo. Hydrobiologia 541: 71-85.

Dadon, J.R. 1995. Calor y temperatura en cuerpos lenticos. In: E.C. Lopretto \& G. Tell (eds.). Ecosistemas de águas continentales: metodologia para su estúdio, v. 1. Ediciones Sur, Buenos Aires, pp. 47-56.

Ferragut, C. 2004. Respostas das algas perifíticas e planctônicas à manipulação de nutrientes $(\mathrm{N}$ e $\mathrm{P}) \mathrm{em}$ reservatório urbano (Lago do IAG, São Paulo). Doctoral Dissertation, Universidade Estadual Paulista, Rio Claro.
Fonseca, B.M. 2005. Diversidade fitoplanctônica como discriminador ambiental em dois reservatórios rasos com diferentes estados tróficos no Parque Estadual das Fontes do Ipiranga, São Paulo, SP. Doctoral Dissertation, Universidade de São Paulo, São Paulo.

Gervais, F. 1998. Ecology of cryptophytes coexisting near a freshwater chemocline. Freshwater Biology 39: 61-78.

Golterman, H.L., Clymo, R.S. \& Ohmstad, M.A.M. 1978. Methods for chemical analysis of freshwaters. 2 ed. Blackwell Scientific Publications, Oxford.

Golterman, H.L. \& Clymo, R.S. 1971. Methods for chemical analysis of freshwaters. International Biological Programmer. Blackwell Scientific Publications, Oxford.

Haffner, G.D. \& McNeely, R. 1989. Community structure in epilimnetic and metalimnetic phytoplankton assemblages. Hydrobiologia 182: 59-71.

Hillebrand, H., Dürseken, D., Kirschiel, D., Pollingher, U.\& Zohary T. 1999. Biovolume calculation for pelagic and benthic microalgae. Journal of Phycology 35: 403-424.

Holopainen, A.L., Niinioja, R. \& Rämö, A. 2003. Seasonal succession, vertical distribution and long term variation of phytoplankton communities in two shallow forest lakes in eastern Finland. Hydrobiologia 506-509: 237-245.

Izaguirre, I., O'Farrell, I., Unrein, F. \& Sinistro, R. 2004. Algal assemblages across a wetland, from a shallow lake to relictual oxbow lakes (Lower Paraná River, South America). Hydrobiologia 511: 25-36.

Jansson, M., Blomqvist, P. \& Jonsson, A. 1996. Nutrient limitation of bacterioplankton, autotrophic and mixotrophic phytoplankton, and heterotrophic nannoflagellates in Lake Örtrãsket. Limnology and Ocenography 41: 1552-1559.

Jones, R.I. 2000. Mixotrophy in planktonic protists: an overview. Freshwater Biology 45: 219-226.

Knapp, C.W., Noyelles, F.J., Graham, D.W. \& Bergin, S. 2003. Physical and chemical conditions surrounding the diurnal vertical migration of Cryptomonas spp. (Cryptophyceae) in a seasonally stratified midwestern reservoir (USA). Journal of Phycology 39: 855-861.

Klaveness, D. 1988. Ecology of the Cryptomonadida: a first review. In: C.D. Sandgren (ed.). Growth and reproductive strategies of freshwater phytoplankton. Cambridge University Press, Cambrigde, pp.105-133.

Kruk, C., Mazzeo, N., Lacerot, G. \& Reynolds, C.S. 2002. Classification schemes for phytoplankton: a local validation of a functional approach to the analysis of species temporal replacement. Journal of Plankton Research 24: 901-912.

Lepistö, L. \& Holopainen, A. 2003. Occurrence of Cryptophyceae and katablepharids in boreal lakes. Hydrobiologia 502: 307-314.

Lopes, M.R.M., Bicudo, C.E.M. \& Ferragut, C. 2005. Spatial and temporal variation of phytoplankton in a 
shallow tropical oligotrophic reservoir, southeast Brazil. Hydrobiologia 542: 235-247.

Lovell, C.R. \& Konopka, A. 1985. Excretion of photosynthetically fixed organic carbon by metalimnetic phytoplankton. Microbial Ecology 11: 1-9.

Lund, J.W.G., Kipling, C. \& LeCren E.D. 1958. The inverted microscope method of estimating algal numbers and statistical basis of estimation by counting. Hydrobiologia 11: 143-170.

Mackereth, F.J.H., Heron, J. \& Talling, J.F. 1978. Water analysis: some revised methods for limnologists. Freshwater Biological Association Publication 39. Titus Wilson \& Son, Kendall.

McCune, B. \& Mefford, M.J. 1999. PC-ORD for Windowns. Multivariate analysis of ecological data, version 4.10. MjM Software Design, Gleneden Beach.

Menezes, M. \& Souza, C.A. 2001. Cryptophyta, Cryptophyceae. In: M. Menezes \& I.C.A. Dias (eds.). Biodiversidade de algas de ambientes continentais do estado do Rio de Janeiro. Série Livros 9. Museu Nacional, Rio de Janeiro, pp. 99-103.

Menezes, M. \& Novarino, G. 2003. How diverse are planktonic cryptomonads in Brazil?: advantages and difficulties of a taxonomic-biogeographical approach. Hydrobiologia 502: 297-306.

Nabout, J.C., Nogueira, I.S. \& Oliveira, L.G. 2006. Phytoplankton community of floodplain lakes of the Araguaia River, Brazil, in the rainy and dry seasons. Journal of Plankton Research 28: 181-193.

Nedbalová, L., Stuchlík, E. \& Strunecký, O. 2006. Phytoplankton of a mountain lake (Ladové pleso, the Tatra Mountains, Slovakia): seasonal development and first indications of a response to decreased acid deposition. Biologia 61(suppl. 18): 91-100.

Novarino, G. 2003. A companion to the identification of cryptomonad flagellates (Cryptophyceae $=$ Cryptomonadea). In: L. Naselli-Flores, J. Padisák \& M.T. Dokulil (eds.). Phytoplankton and equilibrium concept: the ecology of steady-state assemblages. Developments in Hydrobiology 172. Kluwer Academic Publishers, Dordrecht, pp. 225-270.

Ojala,A.1993. Effects of temperature and irradiance on the growth of two freshwater photosynthetic cryptophytes. Journal of Phycology 29: 278-284.

Ramírez R., J.J. 1996. Variações espacial vertical e nictemeral da estrutura da comunidade fitoplanctônica e variáveis ambientais em quatro dias de amostragem de diferentes épocas do ano no Lago das Garças, São Paulo. Doctoral Dissertation, Universidade de São Paulo, São Paulo.

Reynolds, C.S. 1976. Succession and vertical distribution of phytoplankton in response to thermal stratification in a lowland lake, with special reference to nutrient availability. Journal of Ecology 64: 529-551.

Reynolds, C.S. 1984. The ecology of freshwater phytoplankton. Cambridge University Press, Cambridge.

Reynolds, C.S. 1997. Vegetation processes in the pelagic: a model for ecosystem theory. Excellence in Ecology 9, Ecology Institute, Oldendorf.

Reynolds, C.S. \& Reynolds, J.B. 1985. The atypical seasonality of phytoplankton in Close Mere, 1972: an independent test of hypothesis that variability in the physical environment regulates community dynamics and structure. British Phycological Journal 20: 227-242.

Reynolds, C.S., Huszar, V., Kruk, C., Naselli-Flores, L. \& Melo, S. 2002. Towards a functional classification of the freshwater phytoplankton. Journal of Plankton Research 24: 417-428.

Rosen, G. 1981. Phytoplankton indicators and their relations to certain chemical and physical factors. Limnologica 13: 263-296.

Sartory, D.P. \& Grobbelaar, J.U. 1984. Extraction of chlorophyll a from freshwater phytoplankton for spectrophotometric analysis. Hydrobiologia 114: 177-187.

Shepherd, G.J. 1996. Fitopac 1: manual do usuário. Departamento de Botânica, Universidade Estadual de Campinas, Campinas.

Solorzano, L. 1969. Determination of ammonia in natural waters by the phenolhypochlorite method. Limnology and Oceanography 14: 799-801.

Sommer, U. 1981. The role of r- and K- selection in the succession of phytoplankton in Lake Constance. Acta Oecologica: Oecologia Generalis 2: 327-342.

Strickland, J.D.H. \& Parsons, T.R. 1960. A manual of seawater analysis. Bulletin of the Fisheries Research Board of Canada 125: 1-185.

Tucci, A. 2002. Sucessão da comunidade fitoplanctônica de um reservatório urbano e eutrófico, São Paulo, SP, Brasil. Doctoral Dissertation, Universidade Estadual Paulista, Rio Claro.

Utermöhl, H. 1958. Zur vervollkommnung der quantitativen Phytoplankton: Methodik. Mitteilungen der Internationale Vereinigung fur Theoretische und Angewandte Limnologie 9: 1-38.

Valderrama, J.C. 1981. The simultaneous analysis of total nitrogen and total phosphorous in natural waters. Marine Chemistry 10: 109-122.

Vercellino, I.S. 2001. Sucessão da comunidade de algas perifíticas em dois reservatórios do Parque Estadual das Fontes do Ipiranga, São Paulo: influência do estado trófico e do período climatológico. Master of Science Thesis, Universidade Estadual Paulista, Rio Claro.

Wetzel, R.G. 2001. Limnology: lake and river ecosystems. Elsevier Science, Orlando. 